\title{
The use of the Medication Event Monitoring System (MEMS) for assessing medication adherence for chronic conditions: use and results from a 12 month trial of patients in remission with ulcerative colitis (UC)
}

\author{
David Gillespie ${ }^{1 *}$, Kerenza Hood ${ }^{1}$, Andrew Williams', Rachel Stenson², Christopher Probert ${ }^{3}$, Antony Hawthorne ${ }^{2}$
}

From Clinical Trials Methodology Conference 2011

Bristol, UK. 4-5 October 2011

\section{Background}

The Colitis Once Daily Asacol ${ }^{\circledR}$ (CODA) study assessed the efficacy and safety of once daily (OD) dosing with Mesalazine (Asacol ${ }^{\circledR}, 2.4 \mathrm{~g}$ as $3 \times 800 \mathrm{mg}$ tablets) versus one $800 \mathrm{mg}$ tablet three times daily (TDS) over a 12 month period for patients in remission with ulcerative colitis (UC). Emerging evidence suggests OD Mesalazine is as effective as divided doses [1]. While this has been attributed to better adherence, detailed measures of adherence have been lacking in previous studies. A sub study was run alongside in order to provide a more intense monitoring of adherence using the Medication Event Monitoring System (MEMS).

\section{Objectives}

To (i.) describe the use of the MEMS for a detailed assessment of medication adherence and (ii.) present results from the CODA sub study, comparing adherence data collected using the MEMS with the methods used in the main trial.

\section{Methods}

The main CODA trial collected tablet counts at patient visits and asked questions on perceived adherence. The CODA sub study used the MEMS cap data, which electronically recorded the time and date of each cap opening. It was assumed that each cap opening represented a

\footnotetext{
* Correspondence: gillespied1@cardiff.ac.uk

${ }^{1}$ South East Wales Trials Unit, School of Medicine, Cardiff University, UK Full list of author information is available at the end of the article
}

patient taking the correct medication from the bottle [2].

\section{Results}

A total of 58 patients had usable adherence data (49 with complete data (12 months or until relapse), 9 with partial data, 3 patients were withdrawn). The frequency of cap openings split by trial arm will be presented. The percentage of days adherent was significantly different between the two trial arms, with OD patients considerably more adherent than TDS patients. The impact of controlling for adherence on relapse rates will be presented. A comparison will be made between the MEMS adherence data and the adherence data obtained in the main trial. More detailed analysis of patient adherence; including (i.) weekday versus weekend adherence; (ii.) adherence around visit dates versus regular adherence and (iii.) patterns of adherence over time will be considered.

\section{Conclusions}

Collecting adherence data electronically using products such as the MEMS provides an adequate representation of the complexities of patient adherence that may not be possible to obtain through other means (e.g. tablet counts and patient perception).

\section{Acknowledgements}

The trial was supported by an unrestricted educational grant from Warner Chilcott Pharmaceuticals Ltd. The South East Wales Trials Unit is funded by the National Institute for Social Care and Health Research (NISCHR). 


\section{Author details}

${ }^{1}$ South East Wales Trials Unit, School of Medicine, Cardiff University, UK.

${ }^{2}$ Gastroenterology, University Hospital of Wales, UK. ${ }^{3}$ School of Clinical

Sciences, University of Bristol, UK.

Published: 13 December 2011

\section{References}

1. Sandborn W, Korzenik J, Lashner B, et al: Once-daily dosing of delayedrelease oral Mesalamine (400-mg Tablet) is as effective as twice-daily dosing for maintenance of remission of ulcerative colitis. Gastroenterology 2010, 138:1286-1296.

2. Hawthorne $A B$, Stenson R, Gillespie $D$, et al: Assessment of adherence to Mesalazine maintenance therapy over one year using $\mathrm{Mems}^{\circledast}$ monitoring system: a substudy of the CODA trial comparing once versus three times daily Asacol in ulcerative colitis (UC). Gastroenterology 2011, 140:S-264.

doi:10.1186/1745-6215-12-S1-A130

Cite this article as: Gillespie et al.: The use of the Medication Event

Monitoring System (MEMS) for assessing medication adherence for

chronic conditions: use and results from a 12 month trial of patients in remission with ulcerative colitis (UC). Trials 2011 12(Suppl 1):A130.

\section{Submit your next manuscript to BioMed Central} and take full advantage of:

- Convenient online submission

- Thorough peer review

- No space constraints or color figure charges

- Immediate publication on acceptance

- Inclusion in PubMed, CAS, Scopus and Google Scholar

- Research which is freely available for redistribution

Submit your manuscript at www.biomedcentral.com/submit
C Biomed Central 